\title{
Випадок операції герніопластики, уск.ладненої некротизуючим фасціїтом
}

\author{
YU. F. KUSHTA, YU. S. LYSIUK \\ Lviv National Medical University by Danylo Halytskyi
}

\section{CASE OF PLASTIC REPAIR OF INGUINAL HERNIA COMPLICATED BY NECROTIZING FASCIITIS}

\begin{abstract}
В основі статті - випадок герніопластики пахвинної грижі, що ускладнилася виникненням некротизуючого фасціїту. Пацієнт Б. був госпіталізований у клініку в плановому порядку. Після відповідної підготовки та дообстежень його було прооперовано. Внаслідок пластики грижі за способом Бассіні (задньої стінки пахвинного каналу) у пацієнта виник сильний біль у ділянці післяопераційної рани, який не вдалося купірувати введенням знеболювальних, спазмолітиків, нестероїдних протизапальних засобів, навіть наркотичних анальгетиків. На наступний день після операції констатовано зміну кольору країв шкіри (блідо-ціанотичні зливні плями) та виділення геморагічного ексудату з післяопераційної рани. У зв'язку з швидким прогресуванням змін у ділянці рани та калитки виконано повторне операційне втручання некректомію та дренування в межах здорових тканин, оскільки було стверджено наявність анаеробної неклостридіальної флегмони ураженої ділянки тіла. Пацієнт перебував у реанімаційному відділі. Впродовж 12 днів утримувалася стійка гіпотонія інтоксикаційного генезу, постійно вводили вазопресори (дофамін - 5 діб). У зв'язку з проявами дихальної недостатності його було переведено на штучну вентиляцію легень. Щоденно хворому виконували перев'язки з етапними некректоміями. Двічі хірургічні санації проводили в умовах операційної під загальним знеболюванням. Після стабілізації загального стану пацієнт отримав 10 сеансів гіпербаричної оксигенації (ГБО). На 21-шу післяопераційну добу хворого було переведено у спеціалізований відділ для аутодермопластики ділянок пахвини та промежини.
\end{abstract}

There was described a case of inguinal hernia plastic repair that was complicated by necrotizing fasciitis in this article. Patent $B$. was admitted to clinic as a planned patient. After adequate preparing and investigations he underwent surgery. In postoperative period of plastic repair of the inguinal hernia for Bassinie (of the groin rear wall) in the patient acute pain appeared in the area of postoperative wound. There was impossible to reduce intensity of pains or stop (arrest) of pain by injections of analgetics, spasmplitics, nonsteroid anti-inflammatory drugs, even narcotic analgetics. On the next day after operation the changes of color of the wound edges were stated (pale and cyanotic skin spots) and escape of hemorrhagic exudated from the wound. In regard of fast spreading and progressing of changes in area of scrotum and perineum was performed repeated surgery - necroticectomy and draining in area of the healthy tissues, because was confirmed presence of anaerobic nonclostridial phlegmon of affected parts of the body. The patient was in emergency department. During 12 days was stable (persistent) hypotension of intoxication genesis, constantly introduced preparations - vasopressors (dofamin - 5 days). In regard of signs of respiratory insufficiency he was transferred on artificial ventilation of the lungs. Every day was performed dressing with stages necroticectomy. Surgical sanitations of the wounds under general anesthesia were carried out twice - in surgery department. After stabilization of general condition the patient got 10 procedures of hyperbaric oxygenation (HBO). On 21 postoperative day the patient was transferred to specialized department for skin transplantation of perineum and inguinal region.

На сьогодні операція герніопластики пахвинної грижі належить до найбільш розповсюджених в Україні. 3 точки зору бактерійного забруднення, герніопластику вважають прикладом “найчистішої” операції. Поодинокі випадки нагноєнь післяопераційної рани, що майже у 100 \% випадків призводять до рецидиву грижі, розцінюють як надзвичайну подію. Ускладнення герніопластики у вигляді виникнення некротизуючого фасціїту (анаеробної неклостридіальної флегмони) післяопераційної рани в цілому не відоме хірургічній спільноті.

Основною метою роботи було представити випадок планової герніопластики, який усклад- нився фульмінантним перебігом некротизуючого фасціїту.

Пацієнт Б. віком 54 роки був госпіталізований у клініку загальної хірургії у плановому порядку зі скаргами на наявність правобічної пахвинної грижі, яка спричиняла помірний біль та дискомфорт. Після дообстеження та підготовки наступного дня під внутрішньовенним наркозом було виконано пластику задньої стінки пахвинного каналу за способом Бассіні. Приблизно через 1-1,5 год після завершення операції пацієнт відчув сильний “розпираючий” біль у ділянці післяопераційної рани. Ін’єкції традиційних знеболювальних (нестероїдних проти- 
запальних препаратів, анальгетиків) та наркотичних засобів упродовж вечора та ночі не привели до зниження інтенсивності болю. Приблизно через 20 год після операції при огляді рани відмічено зміну кольору шкірних країв (блідо-ціанотичні зливні плями) та виділення 3-поміж швів геморагічного ексудату. У невідкладному порядку виконано дообстеження: при ультразвуковій діагностиці органів черевної порожнини та заочеревинного простору патологічних змін не виявлено; при пальцевому ректальному дослідженні заперечено наявність парапроктиту. У зв’язку із швидким прогресуванням змін у ділянці рани та на калитці, через 22 год після першої операції виконано повторне хірургічне втручання під загальним знеболюванням - констатовано наявність некротичного ураження підшкірної клітковини країв рани (рис. 1) із поширенням по підшкірній фасції на віддаль до 10-15 см від рани на передньо-бокову стінку живота та калитку.

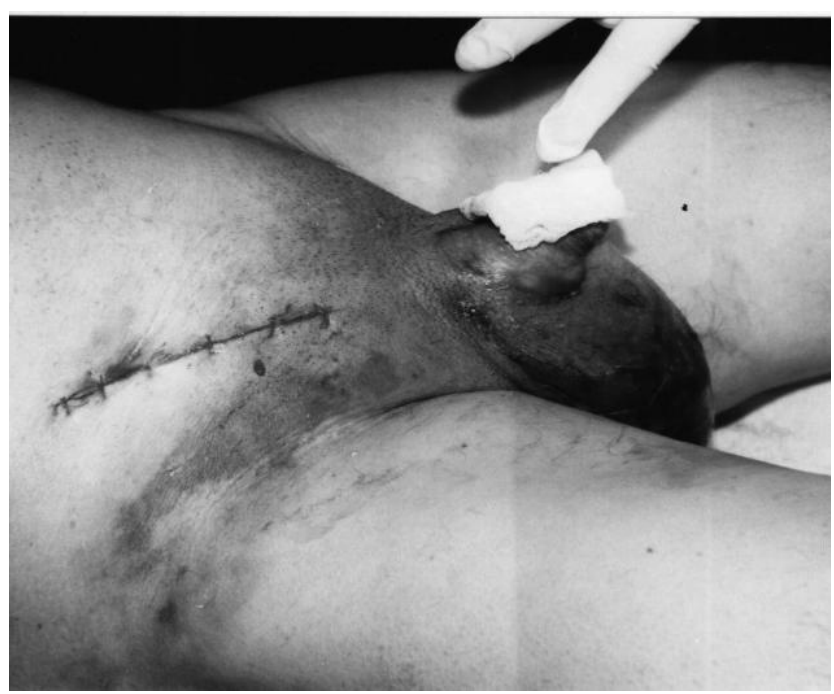

Рис. 1. Некротичне ураження шкіри калитки та країв рани на момент максимальної маніфестації ускладнення.

Даний процес потрактовано як анаеробну неклостридіальну флегмону, було виконано некректомію та дренування в межах здорових тканин. Ранній післяопераційний перебіг тяжкий (рис. 2), пацієнт отримував лікування в умовах реанімаційного відділу протягом 12 діб: відмічали стійку гіпотонію інтоксикаційного генезу, гемодинаміку підтримували постійним введенням вазопресорів (дофамін 5 діб). У зв’язку з проявами дихальної недостатності переведений на штучну вентиляцію легень. Щоденно хворому виконували перев'язки з етапними некректоміями, двічі хірургічні санації проводили в умовах операційної під знеболюванням. Після стабілізації загального стану пацієнт отримав 10 сеансів гіпербаричної оксигенації. Подальший перебіг із позитивними тенденціями, в задовільному

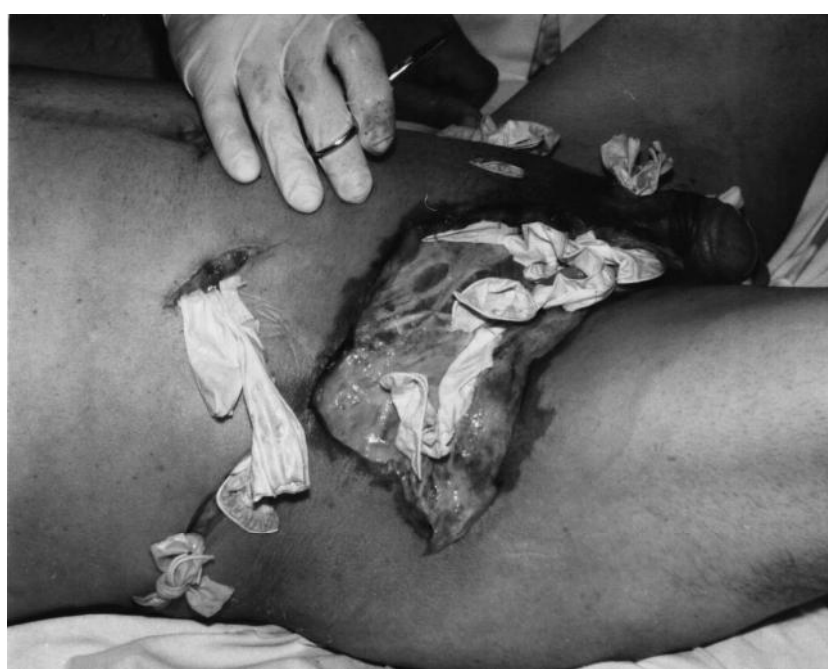

Рис. 2. Стан рани після некректомій (5-та післяопераційна доба).

стані на 21-шу післяопераційну добу переведений у спеціалізоване відділення для аутодермопластики ділянок пахвини та промежини.

При ретроспективному аналізі даного випадку встановлено, що напередодні операції пацієнт відмовився від гоління операційного поля медичною сестрою - в силу ментальних і релігійних особливостей. Це він зробив самостійно, із мікропорізами шкіри калитки, без обробки травмованих ділянок антисептиком чи спиртом. Можливо, некоректне гоління було причиною виникнення такого серйозного ускладнення, оскільки існує висока ймовірність потрапляння анаеробних збудників з прямої кишки на промежину та шкіру калитки.

Обговорення. Хірургічне втручання з приводу неускладнених гриж вважають класичним прикладом “найчистішої” абдомінальної операції. Частота виникнення інфекційних ускладнень після герніопластики перебуває в межах 1-4 \%. У доступній літературі ми не знайшли повідомлень про розвиток некротизуючого фасціїту як ранових ускладнень планових операційних втручань. В окремих публікаціях вказується про рідкість розвитку гангрени Фурньє (ГФ) як різновиду некротизуючого фасціїту внаслідок передопераційного гоління калитки [2], що правдоподібно мало місце у нашому випадку. В поодиноких повідомленнях наводять дані про виникнення ГФ після герніопластики із уточненням, що вказане захворювання переважно спричинюється попереднім хірургічним втручанням на калитці або місцевою інфекцією [2, 3, 5, 7]. Зокрема, у наведеному повідомленні [3] автори зазначають, що їхній випадок - правдоподібно перше повідомлення про ГФ як післяопераційне ускладнення при герніопластиці. Причину виникнення некротизуючої інфекції пов’язують із три- 
валим дренуванням рани (10 діб) та секвестрацією рідини після видалення дренажу, що, ймовірно, призвело до значного збільшення тиску в калитці та послаблення кровопостачання і посприяло розвитку інфекції. Існує обмежена кількість робіт із повідомленнями про ГФ як результат ускладнених пахвинних гриж, при яких некротичне інфекційне ураження м'яких тканин могло розвинутися внаслідок розкриття просвіту кишки під час операції $[3,5]$.

Оптимальне лікування ГФ потребує екстреного хірургічного втручання із максимальним висіченням некротизованих тканин $[1,2,6]$. Радикальність першого втручання та багатократні хірургічні санації залишають пацієнта із великими шкірними дефектами, що потребує шкірної пластики калитки та періанальної ділянки [2, 4]. У нашому випадку було виконано одну повторну хірургічну санацію та в подальшому (на 30-ту добу після першого втручання) - шкірну пластику ранових дефектів пахвини та калитки.

\section{СПИСОК ЛІТЕРАТУРИ}

1. Тимербулатов В. М. Гангрена Фурнье / В. М. Тимербулатов, А. Г. Хасанов, М. В. Тимербулатов // Хирургия. -2009. - № 3. - С. 26-28.

2. Другой взгляд на “болезнь Фурнье в практике хирурга” / А. И. Черепанин, К. В. Светлов, А. Ф. Чернов, Е. В. Бармин // Хирургия. - 2009. - № 10. - С. 47-28.

3. Fournier's Gangrene as a Postoperative Complication of Inguinal Hernia Repair / T. Dinc, S. I. Kayilioglu, I. Sozen // Case Rep Surg [Internet]. - 2014. - Vol. 23.

4. Incarcerated inguinal hernia in the presence of Fournier's gangrene: a novel approach to a complex problem / J. L. Guzzo, G. V. Bochicchio, S. Henry // Am. Surg. - Vol. 2007. -
Новою проблемою герніології можуть стати клінічні ситуації із ускладненою грижею та необхідністю невідкладного хірургічного лікування на фоні місцевої некротизуючої інфекції м'яких тканин [4]. У цьому повідомленні автори описують три послідовних випадки защемленої пахової грижі при ГФ, пропонуючи використовувати лапароскопічний доступ та укріплення черевної стінки сіткою із біоматеріалів.

Висновки. 1. Некротизуючий фасціїт м'яких тканин $є$ рідкісним ускладненням після операції герніопластики пахвинної грижі.

2. Безпосередньою причиною виникнення анаеробного процесу є контактне інфікування м'яких тканин з подальшим потраплянням агресивного збудника в зону пошкодження.

3. При виникненні некротизуючої інфекції м'яких тканин як ранового ускладнення необхідним $\epsilon$ екстрене повторне операційне втручання із радикальною некректомією та подальшими хірургічними санаціями.

Vol. 73 (1). - P. 93-95.

5. Oribabor Fournier's gangrene complicating ruptured Richter's inguinal hernia / U. U. Onakpoya, O. O. Lawal, O. D. Onovo, F. O. // West Afr. J. Med. - 2007. - Vol. 26 (4). - P. 316-318.

6. World Society of Emergency Surgery (WSES) guidelines for management of skin and soft tissue infections / M. Sartelli, M. A. Malangoni, A. K. May [et al.] // World Journal of Emergency Surgery. - 2014. - Vol. 9 (1). - P. 57.

7. Tiong W. H. C. Managing extensive Fournier's gangrene secondary to bilateral, inguinal hernias / W. H. C. Tiong, B. O’Sullivan, T. Ismael / J. Plast. Reconstr. Aesthet. Surg. 2009. - Vol. 62 (11). - P. 533-535.

Отримано 12.03.15 